\title{
Bina Yenileme Uygulamaları için Sürdürülebilirlik Ölçütlerinin Belirlenmesi: Sistematik Literatür Taraması ve Meta Analizi
}

\author{
Determination of Sustainability Criteria for Building Renewal Applications: \\ A Systematic Literature Review and Meta-Analysis
}

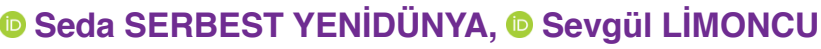

ÖZ

Afet risklerini azaltmak amacıyla yapılan kentsel dönüşüm uygulamaları, afet güvenliğinin sağlanmasının yanında birçok iyileştirmeye olanak sunmaktadır. İyileştirme olanakları arasında yapılı çevrenin sürdürülebilirliğinin sağlanması, binaların olumsuz çevresel, sosyal ve ekonomik etkileri nedeniyle önem kazanmaktadır. Dünya'da yapılı çevrede sürdürülebilirliğin sağlanması amacıyla yapılmış çok sayıda çalışma bulunmaktadır. Ancak sürdürülebilirliğin ülke ve bölgenin yerel bağlamına uygun olarak ele alınması gerekmektedir. Bu nedenle Türkiye'de sürdürülebilir binaların oluşturulması için yerel koşullara uygun, piyasa dinamiklerini göz önünde bulunduran, yasa ve yönetmelikler çerçevesinde oluşturulmuş ve sürdürülebilirliği çevresel, ekonomik, sosyal boyutlarıyla ele alan ölçütlerin belirlenmesi gerekmektedir. Çalışmanın amacı, parsel ölçeğinde bina yenileme uygulamalarının tasarım aşamasında yararlanılmak üzere geliştirilecek yöntem kapsamında kullanılacak sürdürülebilirlik ölçütlerini belirlemektir. Bu amaçla ilk olarak 2009-2018 yılları arasında yayınlanan makaleler sistematik olarak taranmış, sonrasında 22 makale ve beş bina değerlendirme sisteminin konutlar için önerdiği ölçütler analiz edilmiştir. Çalışmada sistematik literatür taraması ve meta analizi ile bina yenileme uygulamalarında kullanılabilecek bir ölçüt seti oluşturulmuştur. Sürdürülebilirliğin çevresel, ekonomik ve sosyal boyutlarını içerecek şekilde oluşturulan dokuz kategoride toplam 68 ölçüt elde edilmiştir. Çalışma, Türkiye koşullarında kentsel dönüşüm kapsamında parsel ölçeğinde gerçekleştirilen bina yenileme uygulamalarının sürdürülebilirliğinin sağlanması için oluşturulacak yönteme girdi oluşturmakta ve bir çerçeve sunmaktadır.

Anahtar sözcükler: Bina yenileme; optimum sürdürülebilirlik ölçütleri; sürdürülebilirlik ölçütleri; yapılı çevrede sürdürülebilirlik.

\section{ABSTRACT}

Urban transformation practices aimed at reducing disaster risks provide many improvement opportunities besides disaster safety. Among these opportunities, ensuring the sustainability of the built environment gains importance due to the negative environmental, social and economic effects of the buildings. A considerable amount of literature has been published around the world on providing sustainability in the built environment. However, sustainability needs to be handled according to the specific local context of the country and the region. In this context, criteria for creating sustainable buildings in Turkey should be determined which considers the local context, market dynamics, law and regulations, environmental, economic and social dimensions. This study aims to identify the sustainability criteria to be used within the scope of the method that will be developed for the design phase of building renewal applications at parcel scale. Accordingly, articles published between $2009-2018$ were systematically reviewed, then the criteria proposed by 22 articles and five building assessment systems for residential buildings were analyzed. In the study, a set of criteria through systematic literature review and meta-analysis has been created that can be used in building renewal applications. A total of 68 criteria were obtained in nine categories including the environmental, economic and social pillars of sustainability. This study provides a framework and input for the method to be established for providing sustainability in building renewals carried out at parcel scale in the context of Turkey's conditions for urban transformation.

Keywords: Building renewal; optimum sustainability criteria; sustainability criteria; sustainability in built environment.

Yıldız Teknik Üniversitesi Mimarlık Fakültesi, Mimarlık Bölümü, Yapı Bilgisi Anabilim Dalı, İstanbul 


\section{Giriş}

Türkiye genelinde ve özellikle İstanbul'da yapılar deprem güvenliğini sağlamak ve riskleri azaltmak amacıyla yenilenmektedir. Marmara Depremi sonrasında devletin önlem çalışmaları kapsamında gerçekleştirilen yasal düzenlemelerden 2012 yılında yayınlanan 6306 sayılı Afet Riski Altındaki Yapıların Yenilenmesi Hakkında Kanun ile kentsel dönüşüm çalışmaları hem alan hem de parsel ölçeğinde hız kazanmıştır.

Parsel ölçeğinde bina yenileme uygulamaları genellikle yüklenici firmalar tarafindan yürütülmekte ve yap-sat yöntemi ile gerçekleştirilmektedir. Yap-sat, konut sahibi olmak isteyenleri bir araya getirerek yüksek arsa fiyatlarının birlikte ödenmesine olanak sağlayan bir mekanizma olarak ortaya çıkmıştr. ${ }^{1}$ Yenileme uygulamalarında ise artan emsaller ve teşvikler sonucu alansal hesaplamalar ile kat maliklerine dairelerinin yenilenerek verildiği, yüklenicinin ise artışlardan yararlanarak daire sayısının artması ile kâr sağladığı bir sistem olarak işlemektedir.

Şehirler depremin dışında birçok farklı sorunla karşı karşıya kalmaktadır. Dünya nüfusunun yarısına ev sahipliği yapan şehirlerde küresel enerjinin büyük bir kısmı tüketilmektedir. Bu nedenle sürdürülebilir kentlerin ve yapılı çevrelerin oluşturulması önem kazanmaktadır. Var olan yapıların yenilenmesi eşzamanlı olarak gerçekleştirilebilecek birçok iyileştirme çalışması ve sürdürülebilirlik ölçütlerinin uygulanabilmesi için bir imkân yaratmaktadır. Ancak bu noktada binaların yenilenmesi uygulamalarında kullanılacak optimum sürdürülebilirlik ölçütlerinin ne olması gerektiği sorusu ortaya çıkmaktadır. Dünyada farklı kurumlar tarafindan oluşturulmuş birçok farklı ölçüt seti bulunmaktadır. Ayrıca bu konuda çok sayıda akademik çalışma yapılmıştır.

Yapı sektöründe her projenin birbirinden farklı olması nedeniyle sürdürülebilirlik çalışmaları için iklimsel, teknolojik, yasal koşulların göz önüne alınması, sektör dinamiklerinin ve aktörlerin tanımlanması önem kazanmaktadır. Bütün bunların bir sonucu olarak Türkiye'de parsel ölçeğinde bina yenilemenin koşullarına uygun ölçütlerin belirlenmesi ihtiyacı doğmaktadır. Ancak, literatürde yer alan çok sayıda sürdürülebilirlik ölçütünün tamamının kullanılması hem girdilerin ele alınmasını zorlaşttracak hem de projenin tamamlanması için kısıtlı süreler gerektiren piyasa koşullarında zaman ve maliyet açısından sorun yaratacaktır. Çalışmada parsel ölçeğinde bina yenileme uygulamalarının tasarım aşamasında yararlanılmak üzere geliştirilecek yöntem kapsamında kullanılacak sürdürülebilirlik ölçütlerinin belirlenmesi amaçlanmaktadır. Bu amaçla ölçütlerin belirlenmesine yönelik uygun çalışmaların bulunması için sistematik literatür taraması yürütülmüş ve meta analizi ile literatürde en sık karşılaşılan sürdürülebilirlik ölçütleri

1 Tekeli, 2010 s. 246 . belirlenmiştir. Çalışma 2009-2018 yılları arasında hakemli dergilerde yayınlanmış ve konut binalarında uygulanabilecek sürdürülebilirlik ölçütlerini öneren çalışmaları kapsamaktadır.

Gerçekleştirilen literatür taraması ve meta analizi bir ölçüt havuzu oluşturulmasını, sıklık analizi ise en çok üzerinde durulan ölçütlerin belirlenmesini sağlamaktadır. En sık kullanılan ölçütlerin ortaya konması Türkiye'de bina yenileme uygulamalarında kullanılacak sürdürülebilirlik ölçütlerinin belirlenmesi için bir altlık oluşturmaktadır.

Türkiye'de var olan konutların 6.7 milyonunun yenilenme ya da güçlendirmeye ihtiyaç duyduğu belirtilmektedir. ${ }^{2}$ Bu nedenle yeni konut uygulamalarında sürdürülebilirliğin sağlanması için yapılacak çalışmalar önem kazanmaktadır.

\section{Yapılı Çevrede Sürdürülebilirlik}

Sanayileşme, kentleşme, nüfus artı̧ı, doğal kaynakların tükenmesi, çevre kirliliğinin artması, iklim değişikliği ve türlerin yok olması gibi karşılaşılan sorunlara çözüm olarak ortaya çıkan sürdürülebilir gelişme kavramı Brundtland Raporu'nda "bugünün gereksinimlerini, gelecek nesillerin kendi gereksinimlerini karşılayabilme olanağından ödün vermeden karşılayan gelişme" olarak tanımlanmaktadır. ${ }^{3}$ 1992 yılında Birleşmiş Milletler tarafindan yayınlanan Rio Deklarasyonu sürdürülebilirliğin üç kolu olan çevresel, sosyal ve ekonomik boyutların dengelenmesini ve ödünleşimler ile önceliklerin belirlenmesini önermektedir. ${ }^{4}$

Son olarak Birleşmiş Milletler tarafindan yürütülen sürdürülebilirlik çalışmaları 2015 yılında yayınlanan sürdürülebilirlik amaçları doğrultusunda devam etmektedir. Bu kapsamda belirlenmiş olan 17 amaç $^{5}$ arasında yer alan sağlık ve kaliteli yaşam, temiz su ve sanitasyon, erişilebilir ve temiz enerji, sürdürülebilir şehirler ve topluluklar, iklim eylemi, sudaki yaşam, karasal yaşam ve amaçlar için ortaklıklar amaçlarının mimarlık alanının katkıda bulunabileceği alanlar olduğu görülmektedir. 1970'li yıllarda yaşanan petrol krizi sonrasında özellikle enerji korunumu ve alternatif enerji kaynaklarının değerlendirilmesi sürecinde yapılı çevre hem kullanım aşamasında tükettiği kaynak ve ürettiği salınımlar hem de tüm sektörün çevresel etkileri nedeniyle önemli bir odak noktası olmuştur.

Yapı sektörü kaynak tüketimi ve çevre kirliliğindeki yüksek payı ve insan yaşamı üzerindeki büyük etkisi nedeniyle sürdürülebilir gelişmede önemli bir role sahiptir. "Dünya nüfusunun yarısı şehirlerde yaşamaktadır ve küresel enerjinin \%67 - 76'sı şehirlerde tüketilmektedir". ${ }^{6}$ Dünya yüzeyinin yaklaşık \%2'sini kapsayan kentsel alanlar toplam kaynak

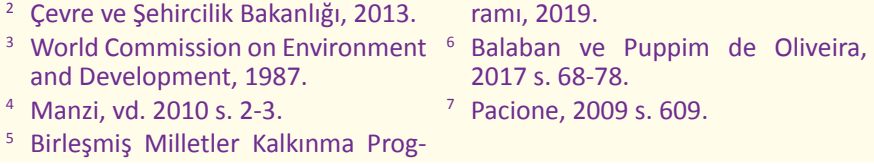


tüketiminin yaklaşık \%75'inden sorumludur. ${ }^{7}$ Şehirleşmenin etkin olduğu özellikle enerji ve kaynak tüketimi konularında şehrin bir bileşeni olan binalar aracılığıyla mimarlık disiplini de yer almaktadır. Yapı sektörü ise küresel kaynakların üçte birini, temiz suyun altıda birini, ahşabın $\% 25$ 'ini ve hammaddelerin \%40'ını kullanmaktadır ve karbon emisyonu, çevresel bozulma ve küresel ısınmada en büyük pay sahiplerinden biridir. ${ }^{8} 2010$ yılı verilerine göre binalar toplam enerjinin \%32'sini tüketmektedir ve yüzyıl ortası için yapılan tahminlerde enerji talebinin iki katnna çıkması ve $\mathrm{CO}_{2}$ salınımının \%50-150 oranında artması beklenmektedir. ${ }^{9} \mathrm{Bu}$ nedenle, sürdürülebilir kalkınma ilkelerini inşaat sektörü uygulamalarına dahil etmek gerekmektedir. ${ }^{10}$

Yapı sektörünün karmaşık yapısı içerisinde, ürünlerin uzun ömürlü doğası, geniş yaşam döngüsü, ürünlerin ve üretim süreçlerinin mekânsal olarak sabitlenmiş yapısı, binaların heterojenliği, sahipler ve kullanıcılar arasındaki tutarsızlık ve mülkiyet değişikliği, yüksek ilk yatırım maliyeti ve çok sayıda küçük ölçekli firmanın baskınlığı gibi özellikler yer almaktadır. ${ }^{11}$ Buna bağlı olarak sektörde yapılacak sürdürülebilirlik çalışmalarının çok boyutlu olarak ele alınması önem kazanmaktadır.

\section{Bina Sürdürülebilirliği Değerlendirme Sistemleri}

Inşaat sektöründe sürdürülebilirliğin sağlanması ve sürdürülebilirlik düzeyinin test edilmesi ihtiyacının bir sonucu olarak bina değerlendirme sistemleri ortaya çıkmıştır. Yeşil bina değerlendirme sistemleri bir binanın belirlenen ölçütlerde beklentileri karşılamak konusunda ne kadar başarılı olduğunu göstermektedir. ${ }^{12} \mathrm{Bu}$ sistemlerin temel amacı bir binanın planlaması, inşaatı ve işletimi sırasında sürdürülebilir uygulamalar ile binanın çevre üzerindeki olumsuz etkisini azaltmaktr. ${ }^{13}$ Değerlendirme sistemleri bir dizi performans ölçütü belirleyerek ve her bir bina projesini bu ölçütlere göre puanlayarak binaların çevresel sürdürülebilirlik performansını değerlendirir. ${ }^{14}$ Yapılar değerlendirme sonucu bir puan ve sertifika almaktadır. Yapının sertifikaya sahip olması sektörde bir art olarak görülmekte ve yapının rekabet gücünü artırmaktadır. Bu nedenle geliştirilen sistemler daha sürdürülebilir bir yapı ortamını teşvik etmekte kullanılan bir çözüm olarak görülmektedir. ${ }^{15}$

Konut yapılarının sektördeki payı nedeniyle sürdürülebilirlik çalışmaları doğrultusunda bina değerlendirme sistemleri genellikle konutları özel olarak ele almaktadır. Avrupa Birliği Ülkeleri'nde konutların tüm yapılar içindeki oranı \%65-80 arasında değişmektedir. ${ }^{16}$ Dünyada sıklıkla kullanılan yeşil bina değerlendirme sistemleri: Amerika

\footnotetext{
8 Doan, vd. 2017 s. 243-260.

1064.

9 Intergovernmental Panel on Cli- ${ }^{13}$ Vyas ve Jha, 2016, s. 313-334. mate Change, 2014 .

${ }^{14}$ Kamali, Hewage ve Milani, 2018, s. 21-41.

${ }^{10}$ Zhang, Shen, Wu, 2011 s. 157-167.

${ }^{11}$ Organisation for Economic Co-op- ${ }^{15}$ Mateus ve Bragança, 2011, s. 1962 eration and Development, 2002. 1971.

${ }^{12}$ Ali ve Al Nsairat, 2009, s. 1053- ${ }^{16}$ European Commission, 2019.
}

Birleşik Devletleri'nde United States Green Building Council (USBGC) tarafindan geliştirilen Leadership in Energy and Environmental Design (LEED), İngiltere'de Building Research Establishment Environmental Assessment Method (BREEAM), Almanya'da Deutsche Gesellschaft für Nachhaltiges Bauen (DGNB) konutlar için özelleşmiş sertifika sistemleri geliştirmişlerdir.

USBGC tarafindan son olarak 2013 yılında güncellenen LEED for Homes and Midrise v.4 konum, arazi, su etkinliği, enerji ve atmosfer, malzemeler ve kaynaklar, iç çevre kalitesi, yenilikçilik ve bölgesel öncelik kategorileri altındaki değerlendirme ölçütleri ile müstakil ve orta yükseklikteki apartman tipi konutları değerlendirmektedir. ${ }^{17}$ BREEAM ise 2018 yılında Home Quality Mark değerlendirme sistemini yayınlamıştır. Ulaşım, dış mekân, güvenlik ve dirençlilik, konfor, enerji, malzeme, mekân, su, kalite garantisi, yapım etkisi, müşteri deneyimi başlıkları altında yer alan ölçütler ile müstakil konutlar ile apartman dairelerinin değerlendirmesi yapılmaktadır. ${ }^{18}$

Yeşil bina değerlendirme sistemleri yerel koşullara uygunluk konusunda ve çevresel sürdürülebilirliğe daha çok önem vermeleri nedeniyle sıklıkla eleştirilmektedir. Bu nedenle birçok akademik çalışma yerel koşullara uygun ve / veya kapsamı genişletilmiş ölçütler belirlemektedir.

Türkiye'de Bina Sürdürülebilirliği Konusunda Çalışmalar

Sürdürülebilirlik kavramı Türkiye'de yakın zamanda ele alınmaya başlamış ve özellikle enerji etkinliği üzerine çaIışmalar yapılmıştır. Türk Standardı TS 825 Binalarda Isı Yalıtım Kuralları 2000 yılında zorunlu hale gelmiştir. 2007 yılında yürürlüğe giren 5627 sayılı Enerji Verimliliği Kanunu sonrasında kanun ile ilgili Binalarda Enerji Performansı Yönetmeliği 2008 yılında yayınlanmıştır. Yönetmelik hem var olan binaları hem de yeni binaları kapsamaktadır ve yapıları enerji ihtiyaçlarına göre etiketlemek için tasarlanmıştır. ${ }^{19}$

Dünyada uygulanan LEED ve BREEAM değerlendirme sistemleri Türkiye'de de kullanılmaktadır. Bu kapsamda 388 LEED sertifikalı, 40 BREEAM sertifikalı proje bulunmaktadır. Bu projelerin çoğunluğu ticari kullanımlı projelerden oluşmaktadır. ${ }^{20}$ Ancak Türkiye'de konut yapılarının tüm yapılar içindeki oranı \%75 olarak belirtilmektedir. ${ }^{21}$ Ayrıca konutlar enerji tüketiminin $\% 21^{\prime}$ lik payından sorumludur. ${ }^{22} \mathrm{Bu}$ nedenle Türkiye'de sürdürülebilir gelişmenin sağlanmasında konut sektörü önemli bir etkiye sahiptir. ${ }^{23}$

2013 yılında Çevre Dostu Yeşil Binalar Derneği (ÇEDBiK) tarafindan yeni konut projelerinde kullanılmak üzere Binalarda Ekolojik ve Sürdürülebilir Tasarım (BEST) sertifika sistemi geliştirilmiştir. Akademisyenler, sivil toplum kuruluşları ve sektör temsilcilerinin iş birliği ile geliştirilen sistem

\footnotetext{
17 USGBC, 2013.

18 BRE, 2018.

${ }^{19}$ Çetiner ve Edis, 2014, s. 132-140.

${ }^{20}$ ÇEDBIK, 2019
} 
bütünleşik yeşil proje yönetimi, arazi kullanımı, su kullanımı, enerji kullanımı, sağlık ve konfor, malzeme ve kaynak kullanımı, konutta yaşam, işletme ve bakım, yenilikçilik kategorileri ile konutları değerlendirmektedir. ${ }^{24}$

Bu çalışmaların yanında Türk Standartları Enstitüsü (TSE) tarafindan yayınlanan Güvenli Yeşil Bina Sertifikası çevreci konut üretmek isteyen Türk yüklenicilerin yurt dışındaki kuruluşların talep ettiği sertifika ücretlerini karşılamakta zorluk çektiği gerekçesi ile oluşturulmuştur. TSE bu çalışmada deprem ve yangın gibi afetlerin yanında malzemelerin sağlığa uygun olması konusunu ele almaktadır. Ayrıca yeşil alan oluşturan ve devamlılığını sağlayan projeler için özel bir puan da eklemektedir. ${ }^{25}$

Mimar Sinan Güzel Sanatlar Üniversitesi tarafindan geliştirilen Sürdürülebilir Enerji Etkin Binalar (SEEB-TR) bina değerlendirme sistemi ise BREEAM (Ingiltere), LEED (ABD), CASBEE (Japonya) ve DGNB (Almanya) sertifikasyon sistemlerinin incelenmesi sonucunda Türkiye koşullarına uygun yeşil bina sertifikasyon sistemi oluşturulması amacıyla geliştirilmiştir. Beş farklı bina tipi (konut, okul, ofis, hastane, otel) ve üç farklı yapım şekli (yeni, yenilenen, var olan) için toplam 15 farklı sertifika grubu tanımlayan sistem 13 ana başlıkta çok sayıda ölçüt sunmaktadır. Sistem çevrimiçi bir yazılım ile desteklenmiştir. ${ }^{26}$

Türkiye'de konut politikasının sürdürülebilir kalkınma ilkelerini bütünleştirici bir şekilde ele alarak düzenlenmesi gerekmektedir. Yeşil binalar, sertifikasyon sistemleri ve teşvik mekanizmaları Türkiye'de sürdürülebilir inşaat uygulamalarının desteklenmesi ve yüklenicilerin yeşil binalar inşa etmeye teşvik edilmesi için bir firsat sunmaktadır. Bununla birlikte kamu kurumlarının öncülük etmek için yatrımlarında sürdürülebilirlik ilkelerine ve sertifikalandırma sistemlerine uymaları gerekmektedir. ${ }^{27}$

\section{Metodoloji ve Bulgular}

Çalışmada ilgili literatürün analizi için sistematik literatür taraması ve meta analizi uygulanmıştir. Sistematik tarama, açıkça formüle edilmiş bir sorun için literatürün, ilgili araştırmayı tanımlamak ve eleştirel olarak değerlendirmek, incelemeye dahil edilen çalışmalardan veri toplamak ve analiz etmek için sistematik ve açık yöntemler kullanarak gözden geçirilmesidir. Meta analizi ise sistematik bir literatür taramasındaki çalışmaların sonuçlarını bütünleştirmek için istatistiksel tekniklerin kullanılmasını ifade etmektedir.

Çalışmada dört adımlı bir akıştan oluşan sistematik incelemeler için tercih edilen raporlama öğeleri (preferred reporting items for systematic reviews- PRISMA) araştrma protokolü kullanılmıştır. PRISMA, 2009 yılında öncelikli olarak sağlık alanındaki araştırmalar için geliştirilmiş bir

\footnotetext{
${ }^{24}$ ÇEDBIK, 2019.

${ }^{25}$ Yeşil Ekonomi, 2013.
}

araştırma protokolüdür. Protokol araştırma adımlarının yanında 27 maddelik bir kontrol listesi sunmaktadır ve araştrmacılara sistematik tarama ve meta analizlerini geliştirmek üzere yardım etmek amacıyla oluşturulmuştur. ${ }^{28}$

\section{Sistematik Literatür Taraması}

Literatür taraması kapsamında aramalar için Scopus veri tabanı kullanılmıştır. Arama "başık / özet / anahtar kelime" alanları ile yapılmıştır. Sürdürülebilirlik alanında yapılan çalışmaların her geçen yıl artması nedeniyle çalışmanın son on yıl ile sınırlanmasının bu kadar hızlı gelişen bir alanda ele alınan çalışmaların güncelliği açısından yararlı olacağı düşünülmüştür. Araştırma 2019 yılında başladığı için 2018 yılı sonuna kadar yayınlanan çalışmalar ele alınmıştr. Bu nedenle tarama zamansal olarak 2009-2018 yılları ile sınırlandırılmıştır.

Aramalarda bina, sürdürülebilirlik, gösterge, ölçüt, mimarlık, değerlendirme sistemi ve sürdürülebilir tasarım anahtar kelimeler olarak kullanılmıştır. Anahtar kelimeler farklı şekillerde bir araya getirilerek Scopus veri tabanında aratılmıştır. Aramalarda bina sürdürülebilirliği ile direkt olarak ilişkili olmayan konu alanları (tp, immünoloji, vb.) arama kapsamı dışında bırakılmıştır. Yayınların tarama kapsamına alınması için:

- hakemli dergide yayınlanmış olması

- Ingilizce olması

- sürdürülebilirlik ölçütleri önermesi

- konut binalarında uygulanabilir olması

şartlarını sağlaması beklenmiştir."

Var olan binalar ve iyileştirme çalışmalarını konu edinen makaleler çalışmaya dahil edilmemiştir. Belirtilen anahtar kelimeler ile yapılan aramalarda toplam 4558 kaynağa ulaşılmıştır. Tekrar eden yayınlar elendikten sonra geriye kalan 3557 makalenin başlıkları bir sonraki aşamaya geçen 603 makalenin ise özleri taranmıs, 175 makale tam metin incelemesi için bir sonraki aşamaya alınmıştı. Literatür taraması sonucunda meta analizinde yer almak üzere 22 makale seçilmiştir. PRISMA protokolü ile yapılan taramanın akışı Şekil 1'de görülmektedir.

Detaylı inceleme için seçilen 22 makaleyi anlatan bir veri çizelgesi oluşturulmuştur. Oluşturulan çizelgede her bir makaleye ait şu veriler yer almaktadır;

- başlık,

- yazar(lar),

- yayın yılı,

- dergi adı,

- çalışmanın amacı,

- çalışmanın yöntemi,

- çalışmanın girdileri/kullandığı veriler,

${ }^{28}$ Moher vd. 2009 s. 1-6. 


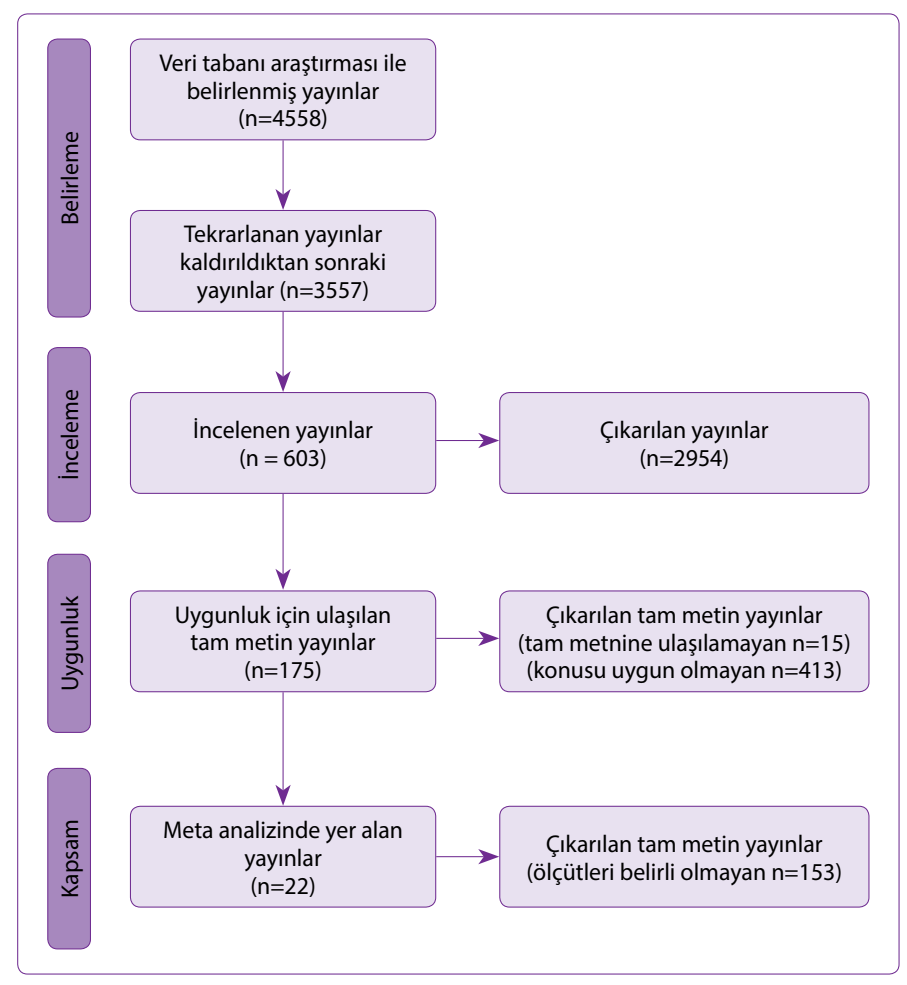

Şekil 1. PRISMA akış şeması.

- çalışmanın konumu,

- uygulama konumu,

- yapı türü,

- ele aldığı sürdürülebilirlik boyutları
Makalelerin özet bilgileri Tablo 1'de görülmektedir.

Çizelgedeki verilerin değerlendirilmesi sonucunda seçilen makalelerde ana konular;

- yerel bağlam,

- kullanım kolaylığı,

- sürdürülebilirliğin üç boyutunun ele alınması

olarak görülmektedir. Makalelerin yarısından fazlası yerel bağlam konusunu ele almaktadır. Bu çalışmalar, literatürdeki ölçütleri yerel koşullar ile ilişkilendirerek kullanabilecekleri sistemler geliştirmişlerdir. Uluslararası yeşil bina sertifika sistemlerinin kullanımında belge sahibi bir uzmana ihtiyaç duyulmaktadır. Kâr paylarının düşük olduğu küçük yükleniciler tarafindan geliştirilen projelerde yeşil bina uzmanına bütçe ayırmak zor olmaktadır. Bunun yerine, kullanım kolaylığı yaratılarak tasarım ekibinin uygulayabileceği sistemler geliştirilmeye çalışılmıştr. Var olan sistemler çevresel boyutu ele aldığı için eleştirilmektedir. Yapılı çevrenin çevresel etkilerinin yanında ekonomik ve sosyal boyutta etkilerinin de olması nedeniyle çalışmalar genellikle binalarda sürdürülebilirliğin üç boyutunun ele alınması konusuna vurgu yapmaktadır.

Uygulanabilirlik alanı incelendiğinde birçok araştırmada ülke özelinde çalışmalar yapıldığı ve çalışmaların çoğunluğunun gelişmekte olan ülkeler için üretildiği görülmektedir. Ölçütlerin belirlenmesi için ele alınan kaynaklar özellikle LEED, BREEAM, DGNB, CASBEE ve SBTool değerlendirme sistemleri olmuştur. Sertifika sistemlerinin yanı sıra var olan akademik çalışmalardan, yasa, yönetmelik ve

Tablo 1. Literatür analizi özeti

\begin{tabular}{|c|c|c|c|c|c|c|c|}
\hline Yazar(lar) & Yıl & Yapı türü & $\begin{array}{l}\text { Sürdürülebilirlik } \\
\text { boyutları }\end{array}$ & Yayının ülkesi & $\begin{array}{l}\text { Uygulanabilirlik } \\
\text { alanı }\end{array}$ & $\begin{array}{l}\text { Ölçütlerin } \\
\text { kaynağı }\end{array}$ & Metodoloji \\
\hline $\begin{array}{l}\text { Kamali, M., } \\
\text { Hewage, K., } \\
\text { Milani, A.S. }\end{array}$ & 2018 & $\begin{array}{l}\text { Modüler } \\
\text { yapılar }\end{array}$ & $\begin{array}{l}\text { Çevresel } \\
\text { Ekonomik } \\
\text { Sosyal }\end{array}$ & Kanada & Küresel & $\begin{array}{l}\text { LEED } \\
\text { Green Globes } \\
\text { LBC } \\
\text { Bilimsel makaleler }\end{array}$ & $\begin{array}{l}\text { Literatür taraması } \\
\text { Uzman görüşmeleri } \\
\text { Analitik Hiyerarşi } \\
\text { Süreci } \\
\text { ELECTRE } \\
\text { TOPSIS }\end{array}$ \\
\hline $\begin{array}{l}\text { Castellano, J., } \\
\text { Ribera, A., } \\
\text { Ciurana, J. }\end{array}$ & 2016 & $\begin{array}{l}\text { Konut } \\
\text { yapıları }\end{array}$ & $\begin{array}{l}\text { Çevresel } \\
\text { Ekonomik } \\
\text { Sosyal }\end{array}$ & İspanya & Küresel & $\begin{array}{l}\text { LEED } \\
\text { BREEAM ES } \\
\text { GBTool }\end{array}$ & Literatür taraması \\
\hline $\begin{array}{l}\text { Tupenaite, L., } \\
\text { Lill, I., } \\
\text { Geipele I., } \\
\text { Naimaviciene J. }\end{array}$ & 2017 & $\begin{array}{l}\text { Konut } \\
\text { yapıları }\end{array}$ & $\begin{array}{l}\text { Çevresel } \\
\text { Ekonomik } \\
\text { Sosyal }\end{array}$ & Litvanya & Baltık Ülkeleri & $\begin{array}{l}\text { Sürdürülebilirlik } \\
\text { değerlendirme } \\
\text { sistemleri } \\
\text { Bilimsel makaleler }\end{array}$ & $\begin{array}{l}\text { Analitik Hiyerarşi } \\
\text { Süreci }\end{array}$ \\
\hline $\begin{array}{l}\text { Chandratilake, } \\
\text { S.R., } \\
\text { Dias, W.P.S. }\end{array}$ & 2015 & $\begin{array}{l}\text { Tüm } \\
\text { yapılar }\end{array}$ & $\begin{array}{l}\text { Çevresel } \\
\text { Sosyal }\end{array}$ & Sri Lanka & Sri Lanka & $\begin{array}{l}\text { BREEAM, CASBEE, } \\
\text { Green Globes, } \\
\text { LEED }\end{array}$ & Sürekli fonksiyonlar \\
\hline
\end{tabular}


Tablo 1. Literatür analizi özeti (devamı)

\begin{tabular}{|c|c|c|c|c|c|c|c|}
\hline Yazar(lar) & YII & Yapı türü & $\begin{array}{l}\text { Sürdürülebilirlik } \\
\text { boyutları }\end{array}$ & Yayının ülkesi & $\begin{array}{l}\text { Uygulanabilirlik } \\
\text { alanı }\end{array}$ & $\begin{array}{l}\text { Ölçütlerin } \\
\text { kaynağı }\end{array}$ & Metodoloji \\
\hline $\begin{array}{l}\text { Al-Jebouri, } \\
\text { M.F.A., } \\
\text { Shaaban, } \\
\text { A.K., Raman, } \\
\text { S.N., Rahmat, } \\
\text { R.A.A.B.O.K. }\end{array}$ & 2017 & $\begin{array}{l}\text { Konut } \\
\text { yapıları }\end{array}$ & Çevresel & $\begin{array}{l}\text { Malezya/ } \\
\text { Umman }\end{array}$ & Umman & $\begin{array}{l}\text { Agenda } 21 \\
\text { Sürdürülebilirlik } \\
\text { değerlendirme } \\
\text { sistemleri }\end{array}$ & Literatür taraması \\
\hline $\begin{array}{l}\text { Tomšič, M., } \\
\text { Zavrl, M.S. }\end{array}$ & 2018 & $\begin{array}{l}\text { Tüm } \\
\text { yapılar }\end{array}$ & $\begin{array}{l}\text { Çevresel } \\
\text { Ekonomik } \\
\text { Sosyal }\end{array}$ & Slovenya & $\begin{array}{l}\text { Avrupa Birliği } \\
\text { Ülkeleri }\end{array}$ & $\begin{array}{l}\text { Sürdürülebilirlik } \\
\text { değerlendirme } \\
\text { sistemleri } \\
\text { CEN TC35 } \\
\text { ISO TC59 }\end{array}$ & $\begin{array}{l}\text { Literatür taraması } \\
\text { Anket }\end{array}$ \\
\hline $\begin{array}{l}\text { Ali, H. H., Al } \\
\text { Nsairat, S.F. }\end{array}$ & 2009 & $\begin{array}{l}\text { Konut } \\
\text { yapıları }\end{array}$ & $\begin{array}{l}\text { Çevresel } \\
\text { Ekonomik } \\
\text { Sosyal }\end{array}$ & Ürdün & Ürdün & $\begin{array}{l}\text { Sürdürülebilirlik } \\
\text { değerlendirme } \\
\text { sistemleri }\end{array}$ & $\begin{array}{l}\text { Anket } \\
\text { Analitik Hiyerarşi } \\
\text { Süreci }\end{array}$ \\
\hline $\begin{array}{l}\text { Mateus, R., } \\
\text { Bragança, L. }\end{array}$ & 2011 & $\begin{array}{l}\text { Konut } \\
\text { yapıları }\end{array}$ & $\begin{array}{l}\text { Çevresel } \\
\text { Ekonomik } \\
\text { Sosyal }\end{array}$ & Portekiz & Portekiz & $\begin{array}{l}\text { SBTool } \\
\text { CEN TC350 } \\
\text { ISO TC59 }\end{array}$ & $\begin{array}{l}\text { Literatür taraması } \\
\text { Değişkenlerin } \\
\text { normalizasyonu } \\
\text { (Diaz-Balteiro } \\
\text { denklemi) } \\
\text { Değişkenlerin } \\
\text { birleştirilmesi }\end{array}$ \\
\hline $\begin{array}{l}\text { Vyas, G.S., } \\
\text { Jha, K.N. }\end{array}$ & 2016 & $\begin{array}{l}\text { Tüm } \\
\text { yapılar }\end{array}$ & Çevresel & Hindistan & Hindistan & $\begin{array}{l}\text { BREEAM, LEED, } \\
\text { SBTool } \\
\text { CASBEE, LEED- } \\
\text { India, GRIHA } \\
\text { Eco-housing }\end{array}$ & $\begin{array}{l}\text { Literatür taraması } \\
\text { Anket } \\
\text { Temel bileşenler } \\
\text { analizi }\end{array}$ \\
\hline $\begin{array}{l}\text { Zarghami, E., } \\
\text { Azemati, H., } \\
\text { Fatourehchi, } \\
\text { D., Karamloo, } \\
\text { M. }\end{array}$ & 2018 & $\begin{array}{l}\text { Konut } \\
\text { yapıları }\end{array}$ & Çevresel & İran & İran & $\begin{array}{l}\text { LEED, BREEAM, } \\
\text { CASBEE } \\
\text { SBTool }\end{array}$ & $\begin{array}{l}\text { Bulanık Analitik } \\
\text { Hiyerarşi Süreci }\end{array}$ \\
\hline $\begin{array}{l}\text { Ahmad, T., } \\
\text { Thaheem, } \\
\text { M.J. }\end{array}$ & 2018 & $\begin{array}{l}\text { Konut } \\
\text { yapıları }\end{array}$ & Ekonomik & Pakistan & Küresel & Bilimsel makaleler & $\begin{array}{l}\text { Anket } \\
\text { Yapılandırılmış } \\
\text { görüşmeler }\end{array}$ \\
\hline $\begin{array}{l}\text { Shao, Q., } \\
\text { Liou, J.J.H., } \\
\text { Weng, S.S., } \\
\text { Chuang, Y.C. }\end{array}$ & 2018 & $\begin{array}{l}\text { Tüm } \\
\text { yapılar }\end{array}$ & Çevresel & Çin & Çin & $\begin{array}{l}\text { Bilimsel makaleler } \\
\text { Sürdürülebilirlik } \\
\text { değerlendirme } \\
\text { sistemleri }\end{array}$ & $\begin{array}{l}\text { Literatür taraması } \\
\text { DEMATEL tabanlı } \\
\text { Analitik Ağ Süreci }\end{array}$ \\
\hline $\begin{array}{l}\text { Ardda, N., } \\
\text { Mateus, R., } \\
\text { Bragança, L. }\end{array}$ & 2018 & $\begin{array}{l}\text { Konut } \\
\text { yapıları }\end{array}$ & Sosyal & Portekiz & Filistin & $\begin{array}{l}\text { ISO 21929-1 } \\
\text { SBTool } \\
\text { Code for } \\
\text { Sustainable } \\
\text { Homes v2 } \\
\text { LEED v4 for homes }\end{array}$ & $\begin{array}{l}\text { Analitik Hiyerarşi } \\
\text { Süreci }\end{array}$ \\
\hline $\begin{array}{l}\text { Abdul- } \\
\text { Rahman, H., } \\
\text { Wang, C., } \\
\text { Wood, L. C., \& } \\
\text { Ebrahimi, M. }\end{array}$ & 2016 & $\begin{array}{l}\text { Konut } \\
\text { yapıları }\end{array}$ & $\begin{array}{l}\text { Çevresel } \\
\text { Ekonomik } \\
\text { Sosyal }\end{array}$ & Malezya & Küresel & $\begin{array}{l}\text { Sürdürülebilirlik } \\
\text { değerlendirme } \\
\text { sistemleri } \\
\text { Bilimsel makaleler }\end{array}$ & $\begin{array}{l}\text { Bulanık Analitik } \\
\text { Hiyerarşi Süreci }\end{array}$ \\
\hline
\end{tabular}


Tablo 1. Literatür analizi özeti (devamı)

\begin{tabular}{|c|c|c|c|c|c|c|c|}
\hline Yazar(lar) & Yıl & Yapı türü & $\begin{array}{l}\text { Sürdürülebilirlik } \\
\text { boyutları }\end{array}$ & Yayının ülkesi & $\begin{array}{l}\text { Uygulanabilirlik } \\
\text { alanı }\end{array}$ & $\begin{array}{l}\text { Ölçütlerin } \\
\text { kaynağı }\end{array}$ & Metodoloji \\
\hline $\begin{array}{l}\text { Conte, E., } \\
\text { Monno, V. }\end{array}$ & 2012 & $\begin{array}{l}\text { Tüm } \\
\text { yapılar }\end{array}$ & $\begin{array}{l}\text { Çevresel } \\
\text { Ekonomik } \\
\text { Sosyal }\end{array}$ & İtalya & Küresel & Bilimsel makaleler & $\begin{array}{l}\text { Literatür taraması } \\
\text { Urban Matrix }\end{array}$ \\
\hline $\begin{array}{l}\text { Alyami, S. H., } \\
\text { Rezgui, Y., } \\
\text { Kwan, A. }\end{array}$ & 2013 & $\begin{array}{l}\text { Tüm } \\
\text { yapılar }\end{array}$ & $\begin{array}{l}\text { Çevresel } \\
\text { Ekonomik } \\
\text { Sosyal }\end{array}$ & Birleşik Krallık & Suudi Arabistan & $\begin{array}{l}\text { BREEAM } \\
\text { LEED } \\
\text { SBTool } \\
\text { CASBEE }\end{array}$ & Delphi yöntemi \\
\hline $\begin{array}{l}\text { Markelj, J. } \\
\text { Kuzman, } \\
\text { M.K., Groselj, } \\
\text { P. Zbasnik- } \\
\text { Senegacnik, } \\
\text { M. }\end{array}$ & 2014 & $\begin{array}{l}\text { Tüm } \\
\text { yapılar }\end{array}$ & $\begin{array}{l}\text { Çevresel } \\
\text { Ekonomik } \\
\text { Sosyal }\end{array}$ & Slovenya & Slovenya & $\begin{array}{l}\text { Sürdürülebilirlik } \\
\text { değerlendirme } \\
\text { sistemleri } \\
\text { Avrupa araştırma } \\
\text { projeleri }\end{array}$ & $\begin{array}{l}\text { Analitik Hiyerarşi } \\
\text { Süreci }\end{array}$ \\
\hline $\begin{array}{l}\text { Roh, S., Tae, } \\
\text { S. Kim, R. }\end{array}$ & 2018 & $\begin{array}{l}\text { Tüm } \\
\text { yapılar }\end{array}$ & Çevresel & Güney Kore & Güney Kore & $\begin{array}{l}\text { Eko-etkinlik- } \\
\text { WBCSD }\end{array}$ & $\begin{array}{l}\text { Etkinlik endeksi } \\
\text { Karbon salınımı } \\
\text { endeksi } \\
\text { Bina yaşanabilirlik } \\
\text { endeksi } \\
\text { Karbon ekonomik } \\
\text { endeksi }\end{array}$ \\
\hline $\begin{array}{l}\text { Patzlaff, } \\
\text { J., Stumpf } \\
\text { Gonzalez, } \\
\text { M. A., Parisi } \\
\text { Kern, A. }\end{array}$ & 2014 & $\begin{array}{l}\text { Tüm } \\
\text { yapılar }\end{array}$ & Çevresel & Brezilya & Brezilya & Bilimsel makaleler & $\begin{array}{l}\text { Literatür taraması } \\
\text { Alan çalışması }\end{array}$ \\
\hline $\begin{array}{l}\text { Zabihi, H. } \\
\text { Habib, F. } \\
\text { Mirsaeedie, L. }\end{array}$ & 2012 & $\begin{array}{l}\text { Tüm } \\
\text { yapılar }\end{array}$ & $\begin{array}{l}\text { Çevresel } \\
\text { Ekonomik } \\
\text { Sosyal }\end{array}$ & İran & İran & Bilimsel makaleler & $\begin{array}{l}\text { Literatür taraması } \\
\text { Anket }\end{array}$ \\
\hline Sev, A. & 2009 & $\begin{array}{l}\text { Tüm } \\
\text { yapılar }\end{array}$ & $\begin{array}{l}\text { Çevresel } \\
\text { Ekonomik } \\
\text { Sosyal }\end{array}$ & Türkiye & Küresel & $\begin{array}{l}\text { Bilimsel makaleler } \\
\text { Akademik } \\
\text { çalışmalar }\end{array}$ & Literatür taraması \\
\hline $\begin{array}{l}\text { Alwisy, A. } \\
\text { BuHamdan } \\
\text { S., Gül, M. }\end{array}$ & 2018 & $\begin{array}{l}\text { Tüm } \\
\text { yapılar }\end{array}$ & Çevresel & Kanada & Küresel & $\begin{array}{l}\text { Sürdürülebilirlik } \\
\text { değerlendirme } \\
\text { sistemleri }\end{array}$ & Sıklık analizi \\
\hline
\end{tabular}

standartlardan yararlanılmaktadır. Makalelerin yöntemleri incelendiğinde ise belirlenen ölçütlerin önem sıralaması ve ağırlıklandırıması için çok kriterli karar verme yöntemleri kullanıldığı gözlemlenmektedir.

\section{Meta Analizi}

Çalışmada sürdürülebilirlik ölçütlerinin belirlenmesi amacıyla öncelikli olarak bir ölçüt havuzu oluşturulmuştur. Bu kapsamda veri tabanı taraması ile bulunan çalışmalarda ve bina değerlendirme sistemlerinde yer alan ölçütler analiz edilerek en sık kullanılan ölçütler belirlenmiştir.
Sistematik tarama sonucunda belirlenen makalelerin önerdiği ölçütlerin yanında dünyada sıklıkla kullanılan bina sürdürülebilirliği değerlendirme sistemlerinin ele aldığı ölçütler de meta analizi kapsamına alınmıştır. Analize katılan değerlendirme sistemleri: Leadership in Energy and Environmental Design (LEED), Building Research Establishment Environmental Assessment Method (BREEAM), Deutsche Gesellschaft für Nachhaltiges Bauen (DGNB), Comprehensive Assessment System for Building Environmental Efficiency (CASBEE), Sustainable Building Tool (SBTool) olarak belirlenmiştir. 
Meta analizinde öncelikli olarak belirlenen çalışmaların ölçütleri kategorilere ayırma şekli incelenmiş, kullanılan kategorilerin sıklıklarına bakılarak ölçüt kategorileri belirlenmiştir. Sürdürülebilirlik ölçütlerini belirlemek amacıyla çalışmaların tüm ölçütlerini içeren ölçüt havuzunda ölçütler kategorilerine göre ayrılmıştır. Daha sonra aynı ya da benzer ölçütler bir araya getirilerek ölçütler arası tekrarın olmadığı bir son liste oluşturulmuştur.

Ölçüt havuzu Türkiye'de parsel ölçeğinde bina yenileme uygulamalarında tasarım aşamasında kullanılacak bir yöntemin altlığını oluşturacağı için parsel ölçeğine uygun olmayan ve konum gibi uygulamaların değiştirilemez boyutlarını ele alan ölçütler de kapsam dışı bırakılmıştı. Ayrıca yasa ve yönetmelikler göz önünde bulundurularak yasal gereklilikler ölçütler arasında tutulmuştur. Sonrasında ölçütler yer aldıkları kategoride bulunma sıklıklarının ele alındığı 1 numaralı denklikte görülen sıklık analizi formülü ile derecelendirilmiştir.

$$
f=\frac{n_{\mathrm{i}}}{\sum n_{i}}
$$

f: sıklık

$n_{i}$ : ölçütün görüldüğü kaynak sayısı

$\sum n_{i}$ : kategorideki toplam kaynak sayısı

Çalışmada belirlenen bina yenileme uygulamaları için kullanılabilecek sürdürülebilirlik ölçütleri kategoriler içinde en sık görülen ölçütlerden oluşmaktadır. Sıklık analizi sonucunda derecelendirilen ölçütlerden kategorinin 0.60-0.80 aralığında anlamlı kısmını oluşturan ölçütler sürdürülebilirlik ölçütleri arasında yer almaktadır. Böylelikle literatürde yer alan çok sayıdaki ölçütün sınırlandırılması sağlanmıştır. Kategoriler ve her kategoride yer alan ölçütler bir sonraki bölümde açıklanmaktadır.

\section{Bina Yenileme Uygulamaları için Sürdürülebilirlik}

\section{Ölçütleri}

Kentsel dönüşüm yöntemlerinden yenileme bir bölgedeki yapıların tamamının veya bir kısmının yıkılıp yeniden inşa edilerek geliştirilmesi olarak tanımlanmaktadır. ${ }^{29}$ Özellikle kent merkezine ve odak noktalarına yakın, ekonomik değeri yüksek ve çeşitli ulaşım olanaklarına sahip alanlar yenileme çalışmalarına ev sahipliği yapmaktadır. Bu alanlar projelerin yenilenmesi sonrasında yüksek ekonomik değerleri devam ettirmeleri nedeni ile yatırımcıların ilgisini çekmektedir. ${ }^{30}$ Parsel ölçeğinde bina yenileme ise genellikle küçük yüklenici firmalar tarafindan uygulanan, var olan bir yapının tekil olarak yıkımı ile yeni yapının yapımını içeren ve tek tek uygulamaların birikmesiyle kentlerin dönüşümünde rol alan ${ }^{31}$ bir yenileme türü olarak tanımlanmaktadır. Çalışma kapsamında bina yenileme uygulamaları

\footnotetext{
${ }^{29}$ Yedekçi, 2015, s. 24.

${ }^{30}$ Serbest Yenidünya ve Limoncu, ${ }^{31}$ Tekeli, 2014, s. 275.
}

etkiledikleri fiziksel koşulların yanı sıra sosyal ve ekonomik etkileri bağlamında da ele alınmaktadır.

İstanbul'da yaygın olarak uygulanan parsel ölçeğinde bina yenilemenin yapım aşamasında geleneksel uygulamalardan farkı olmasa da bina yenileme özellikle tasarım evresi açısından farklılaşmaktadır. Bina yenilemenin başlıca farklılıkları;

- arazinin belirli olması,

- sadece parsel ölçeğinde kararlar içermesi,

- kat maliklerinin hak ve isteklerinin bulunması,

- maliyetin belirleyici bir etken olması,

- tasarım evresinden sonra yıkım evresinin gerçekleşmesi

olarak tanımlanabilmektedir.

ilk fark bina yenilemenin gerçekleştirileceği arazinin belirli olmasıdır. Bu açıdan birçok sistemde önerilen arazi seçimi ve elverişsiz alanların geliştirilmesi önerileri geçersiz kalmaktadır. Diğer yandan uygulamaların daha önceden yapılaşmış bir bölgede yapılmaları ve şehrin merkezi alanlarında, altyapıya erişimi olan bölgelerde uygulanmaları nedeniyle bina yenileme değerlendirme sistemlerinde ele alınan birçok ölçüt açısından avantajlı olmaktadır. İkinci olarak çalışma parsel bazında gerçekleştirildiği için yer seçimi ile ilişkili olarak parsel dışındaki olanakları ele alan ölçütler bina yenileme kapsamında değerlendirilememektedir. Üçüncü fark projenin tasarım aşamasında tasarım ekibinin yanında kat maliklerinin de söz sahibi olması ve tasarım ekibinin kat maliklerinin hakkını ve yüklenici firmanın kâr etmesini sağlayacak bir tasarım üretmesi gerekliliğidir. Bu açıdan tasarım ekibinin ele alması gereken değişkenler geleneksel projelerden farklılaşmaktadır. Bu durum ile ilişkili bir diğer fark olan maliyet küçük yükleniciler açısından önemli bir faktör olarak ele alınmaktadır. Emsal hesaplarına bağlı olarak yüklenicinin mümkün olan en yüksek metrekareye ulaşmaya çalışması sonucu alana yerleşim, mikro klima, çevre yapıların güneşlenme ve rüzgâr alma durumları etkilenmektedir. Ayrıca sürdürülebilirlik konusunda bir uzman danışmanlığı gereksinimi ek maliyet yaratacağından oluşturulan ölçüt setinin bina yenileme uygulamalarında benimsenmesini engelleyecektir. Bu nedenle anlaşılması güç, uzmanlık gerektiren ölçütler ele alınmamış, gereklilikleri net olarak ortaya konan ve kullanım kolaylığı sunan ölçütlere yer verilmiştir. Son olarak bina yenileme sürecinin tasarım evresi sonrasında yapım evresi yerine yıkım evresi ile devam etmesi bina yenilemeyi geleneksel uygulamalardan ayırarak yıkım evresine yönelik ölçütlere de yer verilmesini gerektirmektedir.

Literatür araştırması sonucu belirlenen çalışmaların ele almış olduğu çevresel, ekonomik ve sosyal sürdürülebilirlik ölçütleri literatür taraması ile belirlenen kategoriler altında görülme sıklıklarına göre sıralanmıştır. Kategorilerin litera- 


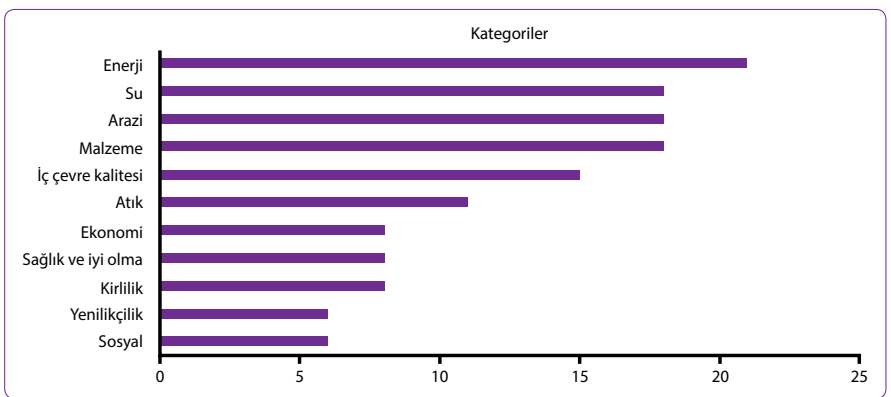

Şekil 2. Kategorilerin sayıları.

tür analizi Şekil 2'de görülmektedir. Bu bağlamda dokuz farklı kategori belirlenmiştir.

Öncelikli olarak kategorilerin belirlenmesi amacıyla yapılan analiz sonucunda 11 başılı ön plana çıkmaktadır. Çalışma kapsamında "sağlık ve iyi olma" başlığı iç çevre kalitesi ile birlikte ele alınmış, "yenilikçilik" kategorisi bina yenileme açısından optimum sürdürülebilirlik ölçütleri arandığı için kapsam dışı kalmıştır.

Meta analizinin ilk aşamasında yer alan 272 ölçüt içerisinde çalışmada kullanılacak ölçütlerin belirlenmesinde ölçütlerin;

- çok genel olmaması,

- parsel ölçeğinde uygulanabilir olması,

- Türkiye'nin sosyo- kültürel bağlamına uygun olması,

- bina yenilemede yer seçimine yönelik ve yer ile ilişkili sabit etmenleri içermemesi,

- kentsel alanlarda gerçekleştirilen projeler ile ilişkili olması

konuları göz önünde bulundurulmuştur. Bunun sonucunda oluşturulan ölçüt seti bina yenileme uygulamalarına uygun, sürdürülebilirliğin üç boyutunu ele alan ve literatürde ön plana çıkan dokuz kategoride toplamda 68 ölçütten oluşmaktadır.

Belirlenen kategorilerde detaylı eleme ve sınıflandırma sonrasında sıklıklarına göre sıralanan ölçütler kategori toplamı 0.60-0.80 aralığında olacak şekilde seçilmiştir. Çaış̧mada ele alınacak ekonomik ve sosyal ölçütlerin sayısını artırmak amacıyla ekonomik ve sosyal kategoriler için ölçütlerin kaynak sayısı az olsa da sıklık toplamı üst sınıra yakın olacak şekilde genişletilerek alınmıştır. Dokuz kategoride belirlenmiş olan 68 ölçüt Şekil 3'te görülmektedir.

\section{Çevresel Sürdürülebilirlik}

Sürdürülebilirliğin üç boyutundan biri olan çevresel sürdürülebilirlik yapılı çevrede yaşam kalitesi iyileştirilirken doğal ve yapay çevrelerin birlikte var olabilmesini, aralarında dengenin sağlanmasını ve bu durumun devamIılı̆ını sağlamayı amaçlamaktadır. Sürdürülebilirliğin çevresel boyutu; arazi, enerji, atık, su, kirlilik, malzeme ve iç çevre olmak üzere yedi başlık altında incelenmiştir. Çevre-

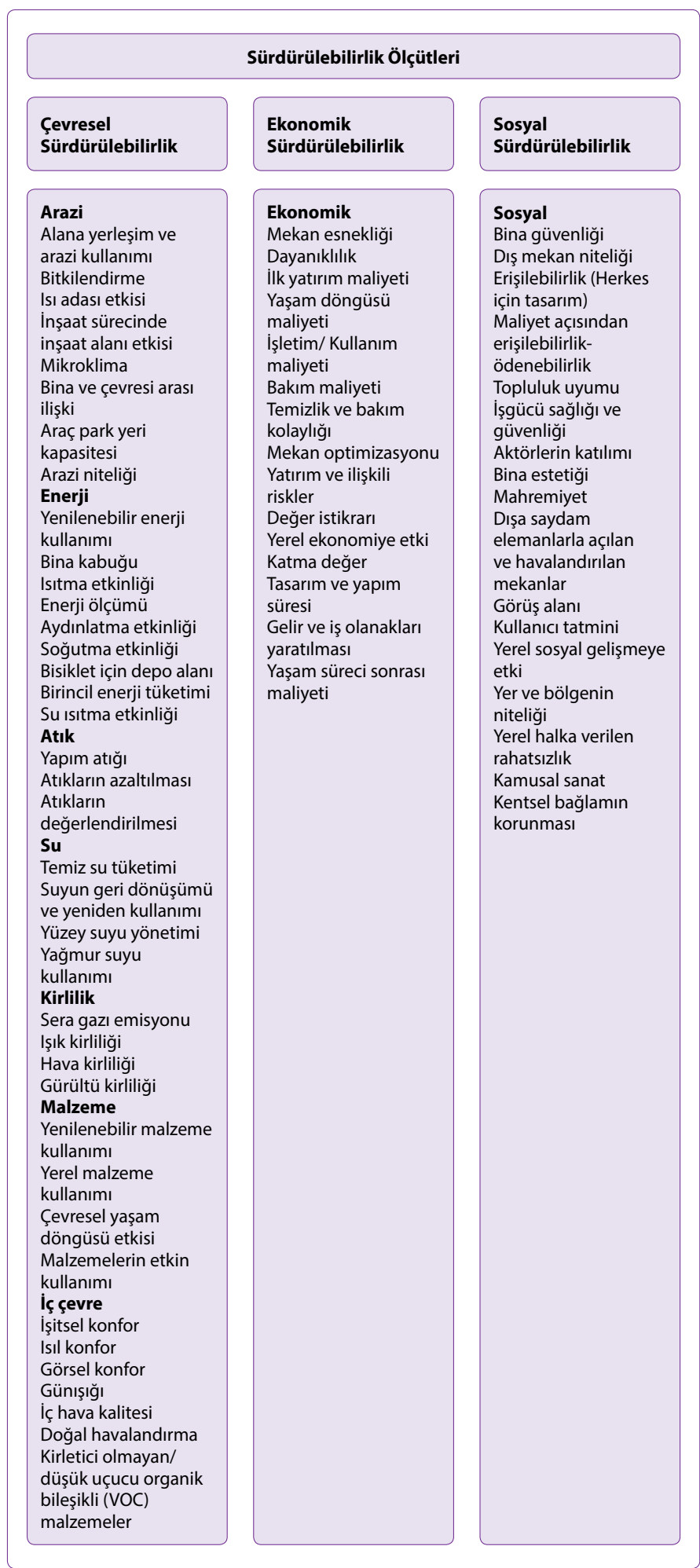

Şekil 3. Sürdürülebilirlik ölçütleri.

sel sürdürülebilirlik kategorisinde toplamda 39 ölçüt yer almaktadır.

Arazi

Arazi başlığı altında sekiz ölçüt bulunmaktadır. Literatürde yer seçimi sıklıkla karşılaşılan bir ölçüt olmasına karşın 
parsel ölçeğinde bina yenileme uygulamalarının tasarım aşamasında değiştirilebilecek bir ölçüt olmaması nedeniyle kapsam dışı kalmıştır. Ele alınan ölçütler alana yerleşim ve arazi kullanımı, bitkilendirme, ısı adası etkisi, inşaat sürecinde inşaat alanı etkisi, mikroklima, bina ve çevresi arası ilişki, araç park yeri kapasitesi, arazi niteliği olarak sıralanmaktadır.

Belirlenen ölçütlerin sıklık toplamı 0.75 olmuştur. Ölçütlerin görülme sıklıkları Şekil 4'te yer almaktadır. Buna göre alana yerleşim ve arazi kullanımı, bitkilendirme ve ısı adası etkisi en çok öne çıkan ölçütler olmuştur.

Arazi kategorisi binanın eğim ile ilişkisi ve yönlenişi hem binanın kendisi hem de komşu yapılar için güneşlenme ve rüzgârdan faydalanma, parsel içerisinde yeşil alan ve sert zemin kararlarını içermektedir. Parselin özellikleri ve binanın yerleşim planı birçok farklı ölçütü etkilemektedir. Tasarım aşamasında alınacak arazi ölçeğindeki ölçütler bütünleşik bir tasarımın oluşturulabilmesi açısından önem kazanmaktadır.

\section{Enerji}

Enerji kategorisinde yer alan dokuz ölçüt; yenilenebilir enerji kullanımı, bina kabuğu, ısıtma etkinliği, enerji ölçümü, aydınlatma etkinliği, soğutma etkinliği, bisiklet için depo alanı, birincil enerji tüketimi ve su ısıtma etkinliği olmuştur. Belirlenen ölçütlerin sıklık toplamı 0.71'dir. Kategoride yer alan ölçütler ve görülme sıklıkları Şekil 5'te sunulmaktadır.

Yenilenebilir enerji kullanımı ve bina kabuğu ölçütleri kategoride öne çıkmaktadır. Enerji kategorisindeki ölçütler genel olarak binanın enerji tüketim miktarını azaltmayı

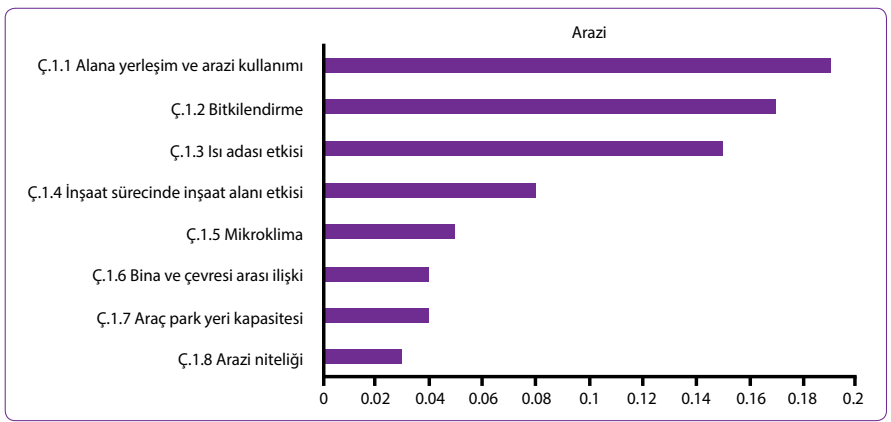

Şekil 4. Arazi kategorisindeki ölçütler ve görülme sıklıkları.

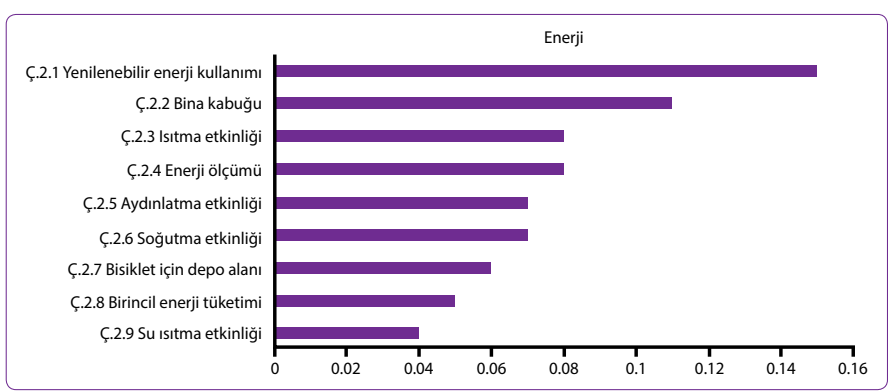

Şekil 5. Enerji kategorisindeki ölçütler ve görülme sıklıkları. ve gereken enerjiyi yenilenebilir kaynaklardan karşılamayı amaçlamaktadır.

Yapılı çevrenin doğal çevre üzerindeki olumsuz etkileri arasında en çok üzerinde durulan konu olan enerjinin çevresel sonuçları yanı sıra ekonomik sonuçları da bulunmaktadır. Bu nedenle konunun optimum sürdürülebilirlik ölçütleri arasında yer alması ekonomik sürdürülebilirliği de olumlu etkileyecektir.

\section{Atik}

Binanın tüm yaşam döngüsü süreçlerinde etkili olan attk konusu özellikle yapım ve kullanım süreçlerinde ele alınmaktadır. Atk kategorisinde yapım atığı, atıkların değerlendirilmesi (ayrıştrılması ve depolanması / kompost ve geri dönüşüm için alan) ve attkların azaltılması olmak üzere üç ölçüt yer almaktadır. Belirlenen ölçütlerin sıklık toplamı 0.76 olmuştur. Ölçütler ve görülme sıklıkları Şekil 6'da görülmektedir.

Yapının tüm yaşam döngüsü süreçlerinde atık hiyerarşisini oluşturan azaltma, yeniden kullanma ve geri dönüşüm olanaklarının bu ölçütler göz önünde bulundurularak değerlendirilmesi gerekmektedir.

\section{Su}

Su konusunda ele alınan ölçütler özellikle binanın kullanım sürecine odaklanmaktadır. Kategoride dört ölçüt yer almaktadır. Bu ölçütler temiz su tüketimi, suyun geri dönüşümü ve yeniden kullanımı, yüzey suyu yönetimi, yağmur suyu kullanımı olarak sıralanmaktadır. Belirlenen ölçütlerin sıklık toplamı 0.71 'dir. Ölçütlerin görülme sıklıkları Şekil 7 'de yer almaktadır.

Su kategorisindeki ölçütlerin ortak amacı binada temiz su tüketimini azaltmaktır. Dünyanın temiz tatlı su kaynaklarının sınırlı olması nedeniyle temiz su tüketimini azaltarak kaynakların korunumuna odaklanan stratejiler geliştirilmesi önemlidir. Ayrıca su konusunda alınacak önlemler afet risklerini azaltması açısından bölgenin direncini artırmaya da katkıda bulunmaktadır.

Kirlilik

Özellikle binanın kullanım sürecinde oluşan çıktılar üzerinden değerlendirilen kirlilik kategorisinde sera gazı salı-

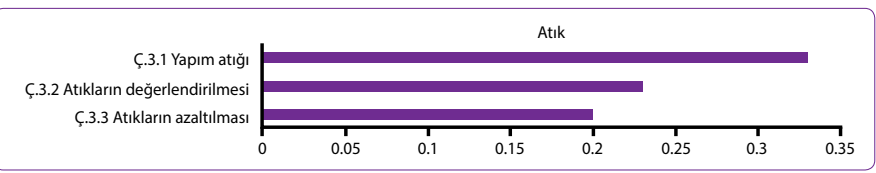

Şekil 6. Atık kategorisindeki ölçütler ve görülme sıklıkları.

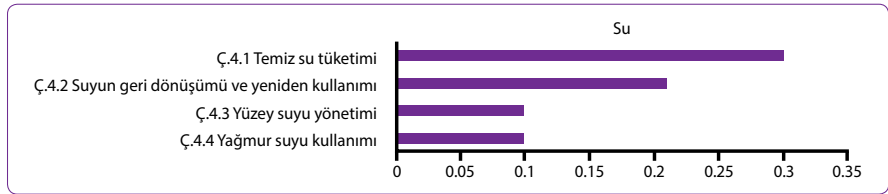

Şekil 7. Su kategorisindeki ölçütler ve görülme sıklıkları. 
nımı, ışık kirliliği, hava kirliliği, gürültü kirliliği olmak üzere dört ölçüt yer almaktadır. Belirlenen ölçütlerin sıklık toplamı 0.64 olmuştur. Ölçütlerin görülme sıklıkları Şekil 8'de sunulmaktadır.

Binanın yapım ve kullanım sürecinde ortaya çıkan ve kirlilik oluşturan çıktılar tasarım aşamasında alınacak önlemler ile azalttlabilmektedir. Kirlilik kategorisinde sıklıkları uygun bulunan ölçütlerin optimum çevresel sürdürülebilirlik ölçütleri arasında yer alması önemlidir. Özellikle bina yenileme uygulamaları yoğun düzendeki şehir dokusu içinde yer aldığından kirlilik tüm binaların yarattğı etki bir araya geldiğinde çözülmesi gereken bir sorun haline gelmektedir.

\section{Malzeme}

Çevresel sorunların en önemlilerinden olan kaynak tüketimini doğrudan etkileyen malzeme kategorisinde dört ölçüt yer almaktadır. Çevre dostu malzeme kullanımı, yerel malzeme kullanımı, çevresel yaşam döngüsü etkisi, malzemelerin etkin kullanımı olarak sıralanan ölçütlerin sıklık toplamı 0.64 'tür. Ölçütler ve görülme sıklıkları Şekil 9'da yer almaktadır.

Malzeme kategorisindeki ölçütler genel olarak kaynak tüketiminin ve çevresel etkinin azaltıımasını amaçlamaktadır. Kaynak tüketiminin ana nedenlerinden olan binalarda malzeme kullanımı konusunda malzemenin nereden geldiği ve yaşam döngüsü süreçlerini ne şekilde devam ettireceği önem taşımaktadır. Binanın bakım onarım süreçlerinde ve servis ömrü sona erdiğinde malzeme kategorisindeki ölçütlere ne şekilde karar verildiği atık kategorisini de etkilemektedir.

\section{iç çevre}

iç çevre kategorisi kullanıcıların fizyolojik gereksinimlerinden yola çıkarak sağlıklı bir ortam oluşturulmasını amaçlamaktadır. Bu kategoride yedi ölçüt yer almaktadır. İşitsel konfor, ısıl konfor, görsel konfor, günışığı, iç hava kalitesi doğal havalandırma, kirletici olmayan/düşük uçucu organik bileşikli (VOC) malzemeler olarak sıralanan ölçütlerin görülme sıklıkları Şekil 10'da verilmektedir. Belirlenen ölçütlerin sıklık toplamı 0.72 olmuştur.

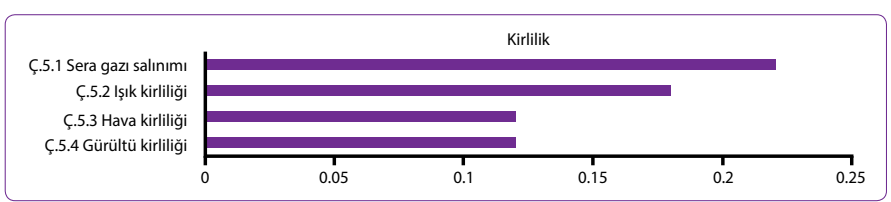

Şekil 8. Kirlilik kategorisindeki ölçütler ve görülme sıklıkları.

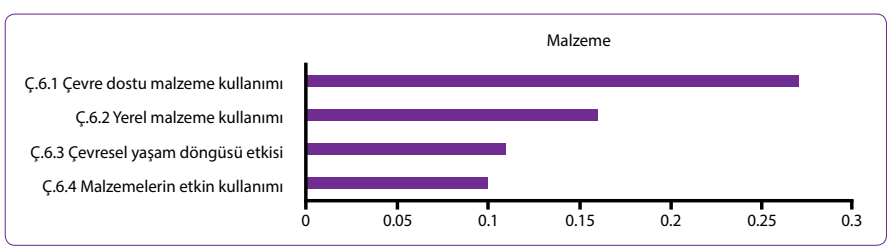

Şekil 9. Malzeme kategorisindeki ölçütler ve görülme sıklıkları.

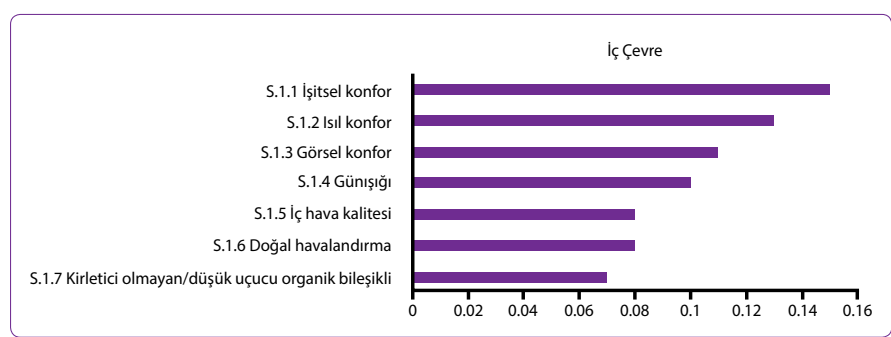

Şekil 10. (a) İç çevre kategorisindeki ölçütler ve görülme sıklıkları.

İç çevre başlığı altında yer alan ölçütlerde işitsel, ısıl ve görsel konfor öne çıkmaktadır. Uygun akustik, ısıl ve görsel koşulların oluşturulması kullanıcıların konforunu sağlayacaktır. Fiziksel etkileri yanında psikolojik etkileri de bulunan iç çevre ölçütleri kullanıcıların yaşam kalitesinin sağlanmasında önem taşımaktadır.

\section{Ekonomik Sürdürülebilirlik}

Ekonomik büyümenin yaşam kalitesini iyileştirerek ve çevreyi koruyarak uzun vadeli olarak sağlanması sürdürülebilirliğin sağlanmasında çok önemlidir. Bu amaçla oluşturulan ekonomik sürdürülebilirlik kategorisinde 15 ölçüt belirlenmiştir. Kategoride bulunan ölçütler; mekân esnekliği, dayanıklıık, ilk yatırım maliyeti, yaşam döngüsü maliyeti, işletim/ kullanım maliyeti, bakım maliyeti, temizlik ve bakım kolaylığı, mekân optimizasyonu, yatırım ve ilişkili riskler, değer istikrarı, yerel ekonomiye etki, katma değer, tasarım ve yapım süresi, gelir ve iş olanakları yaratılması ve yaşam süreci sonrası maliyeti olarak sıralanmaktadır. Belirlenen ölçütlerin sıklık toplamı 0.76 olmuştur.

Ölçütler ve görülme sıklıkları Şekil 11'de sunulmaktadır. Mekân esnekliği, dayanıklıık ve ilk yatırım maliyeti öne çıkan ölçütlerdir. Ekonomik kategorisinde farklı yaşam döngüsü süreçlerinde ortaya çıkan maliyetler, maliyeti etkileyen değişkenler, yerel, bölgesel ekonomi ve ülke ekonomisine katkılar ele alınmaktadır.

Yapıların bina ölçeğinden mahalle, bölge ve ülke ölçeğine uzanan ekonomik etkileri bulunmaktadır. Bu bağlamda bina ölçeğinde uygulanacak ekonomik sürdürülebilirlik ölçütlerinin her ölçekte faydaları olacaktır. Ayrıca binaların

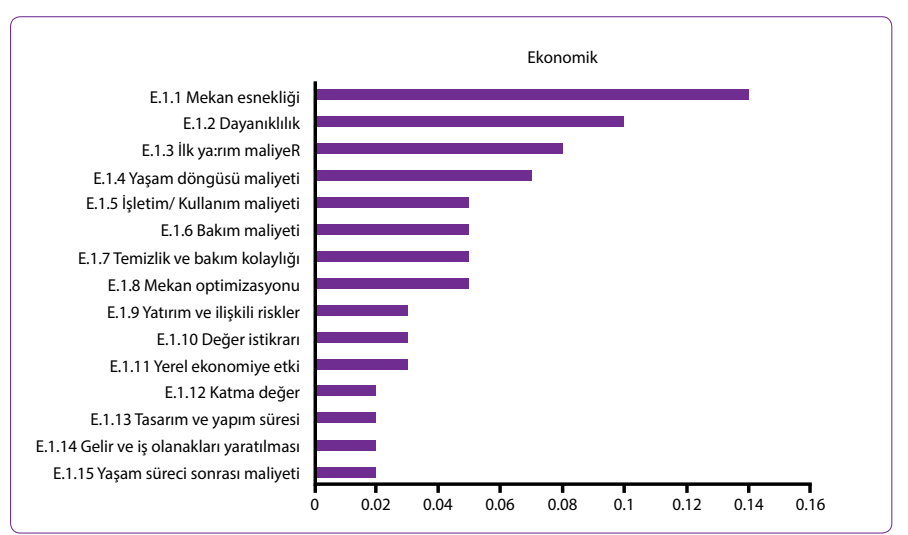

Şekil 11. Ekonomi kategorisindeki ölçütler ve görülme sıklıkları. 


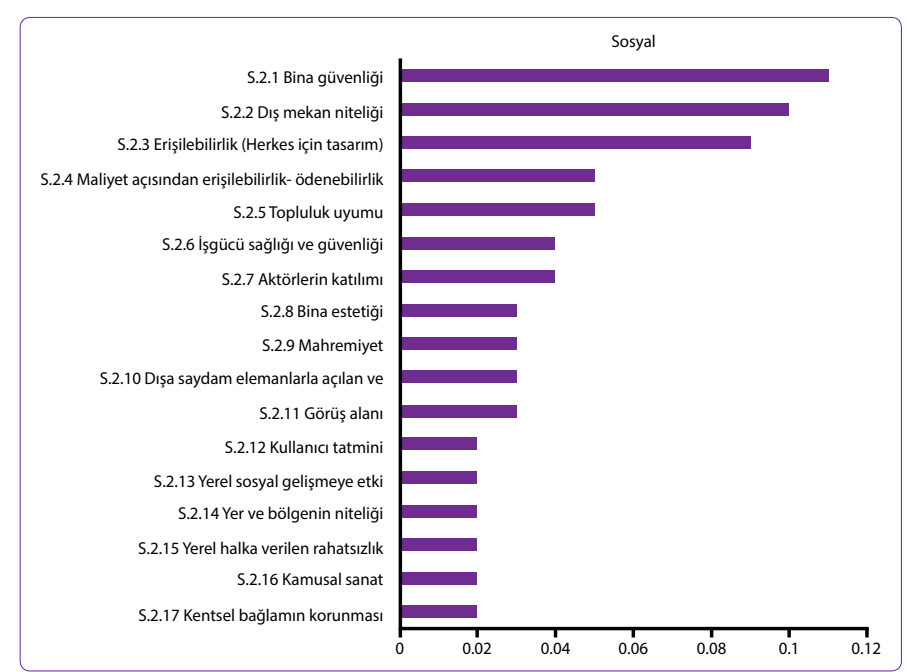

Şekil 12. Sosyal kategorisindeki ölçütler ve görülme sıklıkları.

kullanım süresinin uzun olması uzun vadede devamlılık hedefleyen ekonomik sürdürülebilirlik ilkesinin desteklenmesi açısından yapılı çevrede sağlanacak ölçütlerin önemini artirmaktadır.

\section{Sosyal Sürdürülebilirlik}

Sosyal sürdürülebilirlik kullanıcıların yaşam kalitesini ve topluluk içerisindeki etkileşimleri ele alır. Bu bağlamda yapılı çevrede toplumsal yaşamın ve bireylerin sosyal refahının devamlılığının sağlanması, sosyal ve kültürel hayatın desteklenmesi ve topluluğun gelişmesi için firsatlar yaratılması önem kazanmaktadır.

Kullanıcıların sosyal intiyaçlarına cevap verebilen binalar tasarlamak üzere oluşturulan sosyal sürdürülebilirlik kategorisi 17 ölçütten oluşmaktadır. Bu ölçütler; bina güvenliği, dış mekan niteliği, erişilebilirlik (herkes için tasarım), maliyet açısından erişilebilirlik- ödenebilirlik, topluluk uyumu, işgücü sağlığı ve güvenliği, aktörlerin katılımı, bina estetiği, mahremiyet, dışa saydam elemanlarla açılan ve havalandırılan mekanlar, görüş alanı, kullanıcı memnuniyeti, yerel sosyal gelişmeye etki, yerel halka verilen rahatsızlık, kamusal sanat ve kentsel bağlamın korunması olarak sıralanmaktadır.

Belirlenen ölçütlerin sıklık toplamı 0.72 'dir. Sosyal kategorisinde yer alan ölçütler ve görülme sıklıkları Şekil 12'de verilmektedir. Çalışmalarda bina güvenliği, dış mekân niteliği ve erişilebilirlik ön plana çıkan ölçütler olmuştur.

Bireyleri ve bireyler arası ilişkileri ele alan sosyal ölçütler topluluk halinde ve uyum içinde yaşama, temel sosyal gereksinimlerin sağlanması ve sosyal koşulların iyileştirilmesini amaçlamaktadır. Yaşam alanlarını oluşturan binalar toplumun gönenç seviyesini artırmak için önemli bir role sahiptir. Bu nedenle binaların tasarım aşamasında sosyal boyuttaki sürdürülebilirlik ölçütleri diğer boyutlar ile birlikte ele alınmalıdır.

\section{Sonuç ve Öneriler}

Bina yenileme uygulamalarının Dünya'da sıklıkla görülmeyen yapısı ve Türkiye'de çok sayıda uygulanıyor olması ülke koşullarına uygun, uygulamalara özel bir sürdürülebilirlik çalışmasını gerektirmektedir. Bu çalışmada çevresel, sosyal ve ekonomik ölçütler belirlenmiş ve Türkiye koşullarında bina yenileme uygulamalarının tasarım aşamasında kullanılmak üzere bir ölçüt seti oluşturulmuştur.

Ölçütlerin seçiminde uygulanan, çalışmanın kapsamına yönelik eleme sistemi ile bina yenilemenin ölçeğine uygun, Türkiye'nin sosyo-kültürel bağlamını göz önünde bulunduran ve belirgin, uygulanabilir ölçütler içeren bir ölçüt seti oluşturulmuştur. Literatürde sıklıkla geçen bazı ölçütlerin bina yenileme için uygun olmadığı görülmektedir.

Çevresel sürdürülebilirlik boyutunda yer alan kategoriler ve ölçütler değerlendirilerek bina yenileme uygulamalarının koşullarına uygun olan ve çalışma kapsamına alınacak ölçütler belirlenmiştir;

- Arazi kategorisinde arazi seçimi, çoklu yapı üretimine ilişkin kararları içeren ve kentsel alan dışındaki yapılar için geliştirilmiş ölçütler kapsam dışı kalmıştır. Kategoride yer alan ölçütlerin bir kısmının eski yapıdan kaynaklanan koşullar nedeniyle kısıtlanmakta olduğu görülmektedir.

- Enerji ile ilişkili ölçütlerde alternatif ulaşım gibi genel ve bina yenilemenin ölçeğinin dışında yer alan ölçütler elenerek yönetmelikler tarafindan da desteklenen ölçütlere yer verilmiştir.

- Atkk kategorisinde attk yönetimi gibi genel ölçütler kapsam dışı bırakılmıştır.

- Su kategorisinde genel ölçütler kapsam dışı bıra-

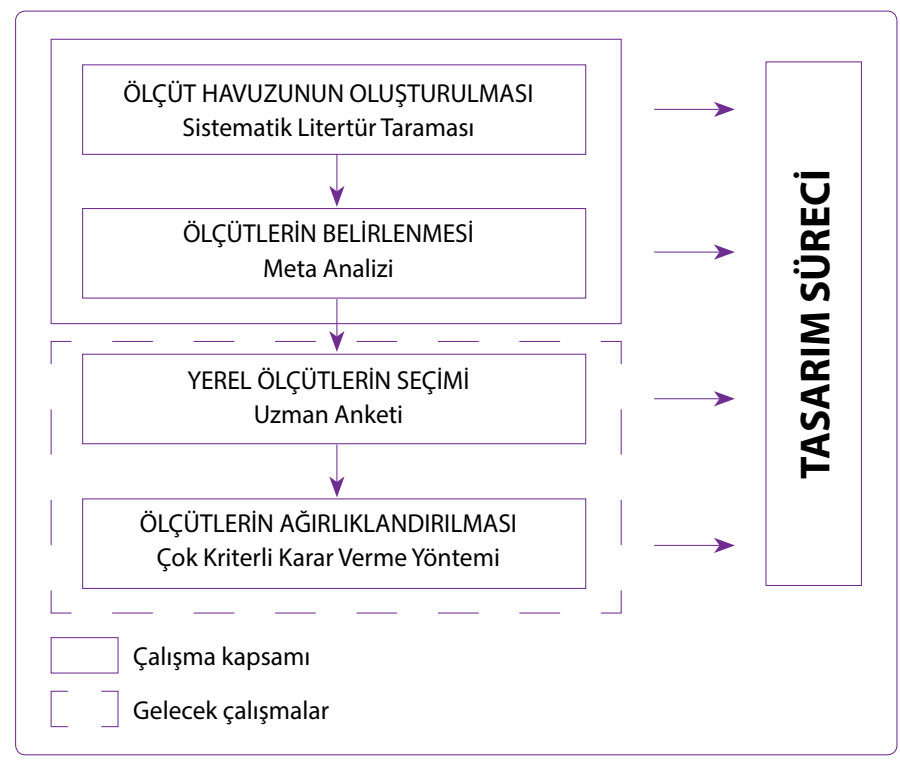

Şekil 13. Çalışmanın kuramsal çerçevesi. 
kılmış, strateji olarak temiz su tüketimini azaltmayı amaçlayan ölçütler bir arada değerlendirilmiştir.

- Kirlilik konusunda bina yenilemenin ölçeğine uygun olmayan ölçütler elenmiştir.

- Malzeme ölçütlerinde literatürde yer alan ölçütler ile bina yenilemenin kapsamına uygun ölçütler arasında bir fark bulunmamaktadır.

- İç çevrede yer alan ölçütler kullanıcı konforunu ele aldığı için bina yenileme uygulamalarında farklılaşmamaktadır.

Ekonomik sürdürülebilirlik altnnda yer alan ölçütler yüklenici ve ülke ekonomisi açısından ele alınarak hem yüklenicinin hem de kullanıcıların fayda sağlayabileceği ölçütlere yer verilmiştir. Bina yenilemenin mülkiyet modeline uygun olmayan ölçütler ile çok genel, uygulama zorluğu yaratacak ölçütler kapsam dışı kalmıştır. Sosyal sürdürülebilirlik hem bina kullanıcılarının sosyal koşullarını hem de binanın bulunduğu bölgenin sosyal koşullarını etkileyecek ölçütleri ele almaktadır. Bölgesel etkileri olan ölçütler tek tek yenilenen binalar ile dönüşen çevrelerde önem kazanmaktadır. Sürdürülebilirliğin sosyal boyutunda bina yenilemenin etki alanı dışında kalabilecek büyük ölçekli ölçütler elenmiştir.

Kategoriler arasında enerji, su, arazi, malzeme ve iç çevre kalitesi öne çıkan başlıklar olmuştur. Enerji kategorisi genel olarak kullanıcı konforu sağlanırken küresel ısınma, kaynakların tükenmesi sorunlarına bağlı olarak çevresel etkileri azaltmayı amaçlamaktadır. Su kategorisindeki ölçütler dünyanın temiz su kaynaklarının tükenmesi nedeniyle temiz su tüketimini azaltmak için farklı teknolojilerden yararlanmayı içermektedir. Arazi kategorisi arazi kararlarının enerji, çevre ile ilişki, iç çevre kalitesi gibi birçok farklı değişkeni etkilemesi nedeniyle önem kazanmaktadır. Malzeme kategorisi, dünyada kaynakların hızla tükenmesi ile ilişkili olarak, malzeme kullanımında kaynak tüketimi ve sonrasında attk üretimini etkilemesi açısından öne çıkmaktadır. iç çevre kategorisi ise kullanıcıların fizyolojik ve psikolojik ihtiyaçlarının uygun şekilde karşılanmasını içermektedir.

Çevresel sürdürülebilirlik konusunda alana yerleşim ve arazi kullanımı, bitkilendirme, Isı adası etkisi, yenilenebilir enerji kullanımı, temiz su tüketimi, suyun geri dönüşümü ve yeniden kullanımı, çevre dostu malzeme kullanımı ölçütleri önemli bulunmuştur. Ekonomik sürdürülebilirlik konusunda mekan esnekliği, dayanıklılık ve ilk yatırım maliyeti ön plana çıkmaktadır. Sosyal sürdürülebilirlik konusunda ise işitsel, ısıl ve görsel konfor, bina güvenliği, dış mekân niteliği ve erişilebilirlik literatürde en sık karşılaşılan ölçütlerdir.

Meta analizi sonuçlarına bakıldığında sürdürülebilirliğin çevresel boyutundaki ölçütlere literatürde daha fazla yer verildiği görülmektedir. Ölçütleri öncelikli olarak sürdürülebilirlik boyutları ve kategorilere ayırmak sıklık açısından bakıldığında tek bir sürdürülebilirlik boyutunda yoğunlaşııma- masını sağlamaktadır. Tüm ölçütleri kendi kategorisi içindeki sıklık açısından değerlendirmek sürdürülebilirliğin üç boyutu arasında denge kurmak açısından önem kazanmaktadır.

Belirlenen ölçütlerin sayısının fazla olması hem bina yenileme uygulamalarında uygulama zorluğu hem de çok kriterli karar verme yöntemlerinde kullanımının karmaşıklığı nedeniyle sorun oluşturmaktadır. Ayrıca oluşturulan ölçüt seti sadece literatürde yer alan ölçütleri içermekte ve ülkenin özel koşullarını göz önüne almamaktadır. Sistematik literatür taraması sonucunda ele alınan 22 makalede vurgulanan, yerel bağlam, kullanım kolaylığı ve sürdürülebilirliğin üç boyutuyla ele alınması konuları bina yenileme uygulamalarına yönelik geliştirilecek bir yöntem için ana gereklilikleri oluşturmaktadır. Bu gerekliliklerin sağlanabilmesi için bina yenilemenin koşullarının ve ölçütlerinin bütün aktörler açısından ele alınması ve çalışmada belirlenen ölçütlerin yerel aktörlerin görüşüne sunulması önem kazanmaktadır. Bu bağlamda, çalışmanın bir sonraki adımı uzman görüşü ile bina yenileme uygulamaları için en önemli ölçütlerin belirlenmesi, ölçütlerin ağırlıklandırılması ve seçimine yönelik geliştirilen yöntemin test edilmesi olacaktır. Alan çalışmaları ve sektör temsilcileri ile yapılacak görüşmelerin yöntemin uygulanabilirliğini artıracağı düşünülmektedir. Literatür taraması ve meta analizini sonucuna dayanarak oluşturulan ölçüt setinin tasarlanan ve Şekil 13'te gösterilen kuramsal çerçevede girdi olarak kullanılması önerilmektedir. Yenilenmesi planlanan çok sayıda konut binası için oluşturulan öneri çerçevenin sürdürülebilirliğin üç boyutunu da ele alan ve çalışmadaki metodoloji ile belirlenen çevresel, ekonomik ve sosyal ölçütler doğrultusunda tasarlanması; ülke ekonomisi, kaynakların sürdürülebilirliği ve kullanıcı konforu ve sağlığı açısından önemlidir. Bu çalışmanın aynı amaca sahip gelecek çalışmalar için bir rehber olacağı düşünülmektedir.

\section{Kaynaklar}

Abdul-Rahman, H., Wang, C., Wood, L. C., Ebrahimi, M. (2016) "Integrating and Ranking Sustainability Criteria for Housing", Engineering Sustainability, 169(1), 3-30.

Ahmad, T., Thaheem, M. J. (2018) "Economic Sustainability Assessment of Residential Buildings: A Dedicated Assessment Framework and Implications for BIM", Sustainable Cities and Society, 38(4), 476-491.

Ali, H. H., Al Nsairat, S. F. (2009) "Developing a Green Building Assessment Tool for Developing Countries - Case of Jordan", Building and Environment 44(5), 1053-1064.

Al-Jebouri, M. F. A., Shaaban, A. K., Raman, S. N., Rahmat, Atiq, R., Rahmat, A. B. O. K. (2017) "Framework of Environmental Rating System for Home Buildings in Oman", Journal of Architectural Engineering, 23(2).

Alyami, S. H., Rezgui, Y., Kwan, A. (2013) “Developing Sustainable Building Assessment Scheme for Saudi Arabia: Delphi Consultation Approach" Renewable and Sustainable Energy Reviews, 27, 43-54. 
Alwisy, A. BuHamdan, S., Gül, M. (2018) “Criteria-Based Ranking of Green Building Design Factors According to Leading Rating Systems", Energy and Buildings, 178, 347-359.

Ardda, N., Mateus, R., Bragança, L. (2018) "Methodology to Identify and Prioritise the Social Aspects to be Considered in the Design of More Sustainable Residential Buildings-Application to a Developing Country", Buildings, 8(10), 130-147.

Balaban, O. (2012) "The Negative Effects of Construction Boom on Urban Planning and Environment in Turkey: Unraveling the Role of the Public Sector", Habitat International 36(1), 26-35.

Balaban, O., Puppim de Oliveira, J. A. (2017) "Sustainable Buildings for Healthier Cities: Assessing the Co-benefits of Green Buildings in Japan", Journal of Cleaner Production, 163, 6878.

Birleşmiş Milletler Kalkınma Programı, "Sürdürülebilir Kalkınma Amaçları", UNDP (United Nations Development Program) Türkiye, www.tr.undp.org/content/turkey/tr/home/sustainable-development-goals.html [Erişim tarihi: 09.10.2019].

BRE (Building Research Establishment), (2018) "Home Quality Mark", www.homequalitymark.com/ [Erişim tarihi: 8 Aralık 2019].

Castellano, J., Ribera, A., Ciurana, J. (2016) “Integrated System Approach to Evaluate Social, Environmental and Economics Impacts of Buildings for Users of Housings", Energy and Buildings, $123,106-118$.

Chandratilake, S. R., Dias, W. P. S. (2015) "Ratio Based Indicators and Continuous Score Functions for Better Assessment of Building Sustainability”, Energy, 83(4), 137-143.

Conte, E., Monno, V. (2012) "Beyond the Buildingcentric Approach: A Vision for an Integrated Evaluation of Sustainable Buildings", Environmental Impact Assessment Review, 34, 31-40.

ÇEDBiK (Çevre Dostu Binalar Derneği), www.cedbik.org [Erişim tarihi: 07 Aralık 2019].

Çetiner, I.., Edis, E. (2014) "An Environmental and Economic Sustainability Assessment Method for the Retrofitting of Residential Buildings", Energy and Buildings 74, 132-140.

Çevre ve Şehircilik Bakanlığı, "BEP-TR Sunumu”, www.csb.gov.tr [Erişim tarihi: 21 Ekim 2013].

Doan, D.T., Ghaffarianhoseini, A., Naismith, N., Zhang, T., Ghaffarianhoseini, A., Tookey, J. (2017) “A Critical Comparison of Green Building Rating Systems", Building and Environment, 123, 243-260.

Eko Yapı Dergisi, (2014) “Türkiye'nin Ulusal Yeşil Bina Sertifikasyon Sistemi 'SEEB-.TR' Tanıtıldı 8 Ocak 2014”, www.ekoyapidergisi.org/337-turkiyenin-ulusal-yesil-bina-.sertifikasyonsistemi-seeb-tr-tanitildi.html [Erişim tarihi:22 Ocak 2020].

Enerji ve Tabii Kaynaklar Bakanlığı, (2018) “ETKB - 2018 Yılı Genel Enerji Dengesi Tablosu", www.eigm.gov.tr/tr-TR/Denge-Tablolari/Denge-Tablolari [Erişim tarihi: 21 Ocak 2020].

European Commission, "An Heterogeneous Building Stock across Europe", https://ec.europa.eu/energy/content/ heterogeneous-building-stock-accross-europe_en?redir=1 [Erişim tarihi:15 Aralık 2019].

Intergovernmental Panel on Climate Change (IPCC), (2014) Summary for Policymakers. In: Climate Change 2014: Mitigation of Climate Change. Contribution of Working Group III to the Fifth Assessment Report of the Intergovernmental Panel on Climate Change, Cambridge, Cambridge University Press.

Kamali, M., Hewage, K., Milani, A.S. (2018) "Life Cycle Sustaina- bility Performance Assessment Framework for Residential Modular Buildings: Aggregated Sustainability Indices", Building and Environment, 138(6), 21-41.

Manzi, T., Lucas, K., Jones, T. L., Judith Allen, J. (2010) Social Sustainability in Urban Areas London, Earthscan.

Markelj, J., Kuzman, M. K., Grošelj P., Zbašnik-Senegačnik, M. (2014) "A Simplified Method for Evaluating Building Sustainability in the Early Design Phase for Architects", Sustainability, 6, 8775-8795.

Mateus, R., Bragança, L. (2011) "Sustainability Assessment and Rating of Buildings: Developing the Methodology SBToolPTeH", Building and Environment, 46(10), 1962-1971.

Moher, D., Liberati, A., Tetzlaff, J., Altman, D. G. (2009) “Preferred Reporting Items for Systematic Reviews and Meta-Analyses: The PRISMA Statement", PLoS Medicine 6(7),1-6.

Organisation for Economic Co-operation and Development (2002) Design of Sustainable Building Policies: Scope For Improvement And Barriers ENV/EPOC/WPNEP(2001)5/FINAL.

Pacione, M. (2009) Urban Geography a Global Perspective, New York: Routledge.

Patzlaff, J., Stumpf Gonzalez, M. A., Parisi Kern, A. (2014) "The Assessment of Building Sustainability in Micro and Small Building Firms-Case Study on Southern Brazil" Revista Ingenieria de Construccion, 29(2), 151-158.

Roh, S., Tae, S., Kim, R. (2018) “Developing a Green Building Index (Gbl) Certification System to Effectively Reduce Carbon Emissions in South Korea's Building Industry", Sustainability, 10, 1872-1889.

Serbest Yenidünya S., Limoncu S. (2018) "Bina Yenilemenin Aktörler ve Amaçlar Bağlamında Değerlendirilmesi”, I. İstanbul Konut Kurultayı, 14 Mayıs 2018, İstanbul, 36-37.

Sev, A. (2009) "How Can the Construction Industry Contribute to sustainable Development? A Conceptual Framework", Sustainable Development 17, 161-173.

Shao, Q., Liou, J. J. H., Weng, S., Chuang, Y. (2018) “Improving the Green Building Evaluation System in China Based on the DANP Method", Sustainability, 10, 1173.

Tekeli, İ. (2010) Konut Sorununu Konut Sunum Biçimleriyle Düşünmek, İstanbul, Tarih Vakfi Yurt Yayınları.

Tekeli, İ. (2014), Kent, Kentli Hakları, Kentleşme ve Kentsel Dönüşüm, İstanbul, Tarih Vakfi Yurt Yayınları.

Tomšič, M., Zavrl, M.S. (2018) “Development Of a Sustainability Assessment Method for Buildings - the OPEN HOUSE Case", Facilities, 36(1/2), 76-102.

Tupenaite, L., Lill, I., Geipele I., Naimaviciene J. (2017) “Ranking of Sustainability Indicators for Assessment of the New Housing Development Projects: Case of the Baltic States", Resources, 6(4), 55-76.

TÜiK (Türkiye İstatistik Kurumu), "Yapı İzin İstatistikleri", http:// www.tuik.gov.tr/PreTablo.do?alt_id=1055 [Erişim tarihi: 20 Ocak 2020].

USGBC (United States Green Building Council), (2013) "LEED Rating System", www.usgbc.org/leed [Erişim tarihi: 8 Aralık 2019].

Vyas, G. S., Jha, K. N. (2016) “Identification of Green Building Attributes for the Development of an Assessment Tool: A Case Study in India", Civil Engineering and Environmental Systems, 33(4), 313-334.

Yedekçi, G. (2015) Kentsel Dönüşüm, İstanbul, Mimarlık Vakfi İk- 
tisadi İşletmesi.

Yeşil Ekonomi, (2013) "TSE Yeşil Bina Sertifikasyonu Çalışmasını Tamamladı", www.yesilekonomi.com/tse-yesil-binasertifikasyonu-calismasini-tamamladi/ [Erişim tarihi: 22 Ocak 2020].

Zarghami, E., Azemati, H., Fatourehchi, D., Karamloo, M. (2018) "Customizing Well-Known Sustainability Assessment Tools for Iranian Residential Buildings Using Fuzzy Analytic Hierarchy Process", Building and Environment 128(1), 107-128.
World Commission on Environment and Development (1987) "Our Common Future", Oxford, Oxford University Press.

Zabihi, H., Habib, F., Mirsaeedie, L. (2012) "Sustainability Assessment Criteria for Building Systems in Iran", Middle East Journal of Scientific Research, 11(10), 346-1351.

Zhang, X., Shen, L., Wu, Y. (2011) "Green Strategy for Gaining Competitive Advantage in Housing Development: A China Study", Journal of Cleaner Production, 19(2-3), 157-167. 